\title{
Proposal of a Micro Generator Piezoelectric for Portable Devices from the Energy Harvesting
}

\author{
Ando Junior, O. H. ${ }^{1-2}$, Coelho, M. A. J. ${ }^{2}$, Malfatti, C. F. ${ }^{2}$, Brusamarello, V. J. ${ }^{2}$ \\ ${ }^{\mathbf{1}}$ Department of Electrical Engineering \\ SATC, Beneficent Association of Santa Catarina Coal Industry \\ Street Pascoal Meller, 73. Criciúma-SC (Brazil) \\ Phone/Fax number: +55 48 3431-75.50, e-mail: oswaldo.junior@satc.edu.br \\ ${ }^{2}$ School of Engineering \\ UFRGS, Federal University of Rio Grande do Sul \\ Av. Osvaldo Aranha, 103. Porto Alegre-RS (Brazil) \\ Phone/Fax number: +55 51 3308-42.78, e-mail: marcos.coelho@ufrgs.br, celia.malfatti@ufrgs.br, \\ valner.brusamarello@ufrgs.br
}

\begin{abstract}
.
This paper presents a proposal for clean energy generation through the Piezoelectricity PZT via piezoelectric cells that convert mechanical energy through the deformation of the material into electrical energy to recharge and power portable devices. This research presents a proposal for capturing mechanical energy used daily by the entire world population and the movement of the walk, where a pressure is generated in footwear and soil, is pressure is being transformed into deformation and the mechanical energy required for piezoelectric cells generate electricity. The energy generated by a piezoelectric single cell is relatively small, necessitating the use of multiple cells in a small contact area to increase the power generated by the system. The treatment of the signal generated by the cells is accomplished with piezoelectric rectification and filtering stages where the signal pulse generated is converted continuously being stored in capacitors. Ends up presenting a prototype mounted on a shoe to carry out tests and measurements of the system in order to ascertain the capacity to generate electricity from the piezoelectric effect, given that the energy generated by the system not currently used for any finally, thereby being wasted.
\end{abstract}

\section{Key words}

Alternative Energy, Electric Power Generation, Piezoelectricity, Portable devices.

\section{Introduction}

The demand for electricity is growing worldwide, with increasingly frequent use of handheld devices by population, and consequently the increase in demand for battery power and other energy sources are needed for recharging, nowadays most are sources polluters and disposable. Thus, evidence an opportunity for the development and use of micro alternative sources from clean energy sources for the sustainability of the planet.
The use of clean energy generation by piezoelectric transducers that convert mechanical energy from a mechanical deformation of the material in an electrical field after the treatment that may be used for powering loads through a clean energy is being wasted and daily.

\section{Theoretical Review}

Piezoelectricity is defined as the property of some dielectric materials that have developed a polarization that are subjected to mechanical strain deformation. This mechanical tension produced by the biasing force realignment of atoms thereby creating loads of polarization and thus an electric field $[1,2]$.

Conversely, when a piezoelectric material is subjected to an electric field that will generate a mechanical deformation in its structure. In both applications the reversal in the direction of application of force, mechanical or electrical will generate a reversal in the direction of the effect, the piezoelectric effect is demonstrated in Figure 1 [1, 2].

The common piezoelectric materials include barium titanates and lead, lead zirconate $\left(\mathrm{PbZrO}_{3}\right)$ dihydrogenorthophosphate ammonium phosphate $\left(\mathrm{NH}_{4} \mathrm{H}_{2} \mathrm{PO}_{4}\right)$, lead zirconate titanate, and quartz. This property is characteristic of crystalline materials having complicated structures with a low degree of symmetry [1]. 




(a)

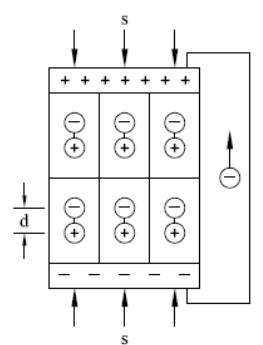

(c)

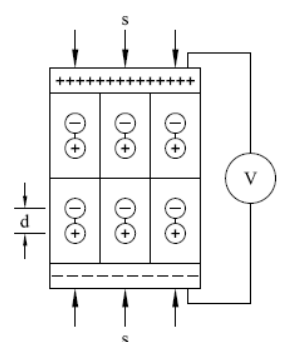

(b)

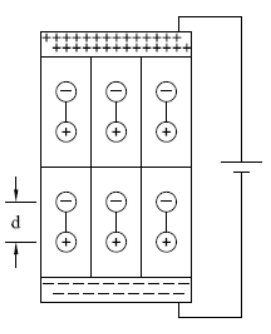

(d)

Fig. 1: Principle of the Piezoelectric Effect [1].

\section{A. Piezoelectric Effect}

The piezoelectric effect is related to the structure and organization of the materials being solid material that has two types of ordering structure, amorphous or crystalline . The amorphous solids do not have oriented chains long distance, so irregular solid $[1,3]$.

Crystalline solids have atoms ordering defined, uniform , dimensional repeatability and long distance. Each type of material has its own organization atoms, for this reason there is a difference between the properties of different materials [3].

As mentioned above, the piezoelectricity is a phenomenon that occurs only in materials with crystalline structure, and this structure is that the material must have construction with no center of symmetry, because, as can be seen in Figure 2, when there is a material with center symmetric square lattice with inversion symmetry when the electric dipole is formed, both at rest and in the electric dipole resulting deformation is null $[1,3]$.

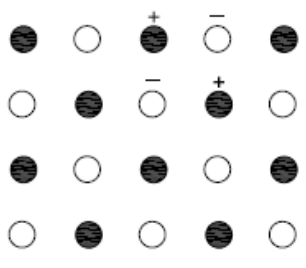

(a)

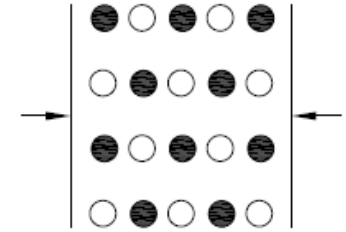

(b)
Fig. 2: Absence of Piezoelectricity in Crystals with Symmetrical Center [2].

For piezoelectric materials as there is no symmetrical center in compression when a crystal that produces an electrical dipole in the direction of deformation of the crystal, Figure 3, for the case without deforming the three dipoles formed by the ion A and its load in the vicinity have zero moment, and when it is subjected to a deformation of the angles between the dipoles are changed, and produce a resultant force in the direction in which it was excited $[2,3]$
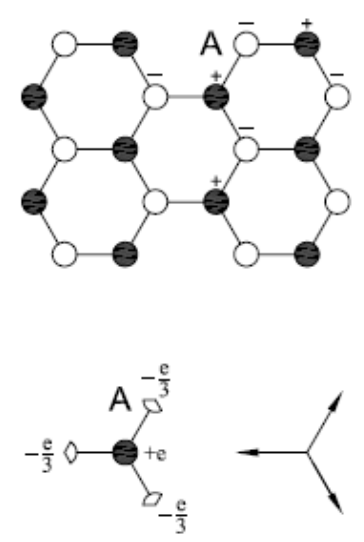

(a)
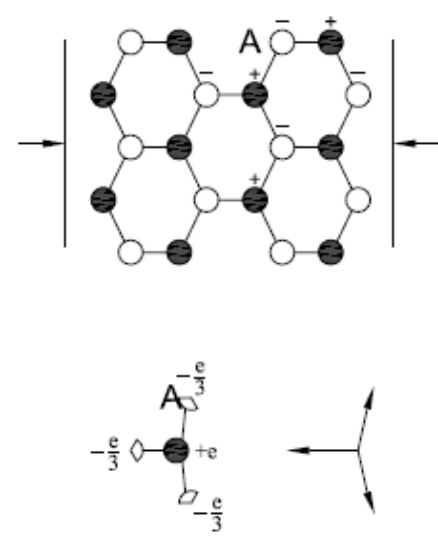

(b)
Fig. 3: Origin of Piezoelectricity [3].

As an example of the PZT type ceramics, the crystals have a crystalline structure Perovskite type that presents symmetry tetragonal, rhombohedral or simple cubic, that according to the temperature that the material is, Figure 4a, when below a certain Curie temperature, known as the critical temperature, the Perovskite-type structure has tetragonal symmetry with the center of symmetry of positive electric charges does not coincide with the center of symmetry of the negative charges, giving rise to an electric dipole, and when above this critical temperature, figure $4 \mathrm{~b}$, is the symmetry of positive electrical charges with the negative, not generating the electric dipole [4].

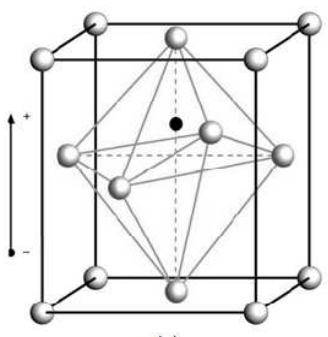

(a)

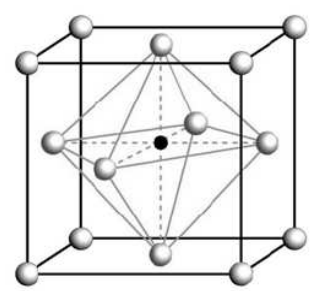

(b)
Fig. 4: Perovskite structure of PZT type piezoelectric ceramic (a) below the Curie temperature. (b) Above the Curie temperature [4].

\section{State of the Art}

The use of the piezoelectric effect to generate energy is already used to power electrical systems in the world, projects that use this type of energy are listed below.

\section{A. Disco Watt, Rotterdam, Netherlands}

Located in the city of Rotterdam in the Netherlands, the disco Watt uses the concept of being nightclub " greener world " where the attendees themselves will be the primary energy mix of clubs using the criteria of the Sustainable Dance Club (SDC) . The energy is collected by piezoelectric sensors installed on the dancefloor and this energy converted to power the lighting environment. To dance on, a person can produce 5-10 watts, depending on your weight and movements are recorded by devices that display a graph of energy, which will be on display , 
serving as a stimulus for the regulars and the more energetically if dance, more energy can be generated [5].

\section{B. Train Station, Shibuya, Japan}

The train station in Shibuya, located in Japan, is testing a new and clever way to generate electricity with the use of piezoelectric cells with the use of platforms named FB 0001 Manufacturer Sound Power, which generate 0.1 to 0 , $3 \mathrm{~W}$ maximum power momentary on an area of $0.25 \mathrm{~m}^{2}$ with a person of $60 \mathrm{~kg}$ in normal stride. Electrical energy is generated with the footsteps of people who walk into the station, where this generation is high because many Japanese use the train on a daily basis [6].

\section{Traffic Flow, Israel}

The generation of energy from the flow of cars crossing a road is the way the company Innowattech, Israel, found to produce energy. With private investment in the amount of \$ 3 million is required to install the sensors beneath sidewalks, roads and rail grids capable of storing energy from the movement and weight through the process of piezoelectric where this energy is normally wasted.

The use in automobile roads with four lanes and a distance of $1.6 \mathrm{~km}$ can generate approximately $400 \mathrm{~kW}$, and the average car is driven by a motor, this energy is enough to power approximately 600 homes [7].

\section{Bar Surya, London, England}

In London, England, the lighting and sound equipment are loads that consume a lot of electricity for this reason to a nightclub called Surya coated the floor of the dance floor with piezoelectric plates, which when pressed by frequenters of the place elegy generate electricity to help power estabelecimento.Com this change energy production across the dance floor is $0 \%$ of the energy needs of the place [8].

\section{E. Town of Toulouse, France}

The city of Toulouse , France, was the first city in the world to test the piezoelectric technology to generate electricity in their streets and sidewalks in accordance with the municipal authorities, eight modules were installed in the downtown area, with each module produced an average power of approximately $60 \mathrm{~W}$, i.e. each such module generates enough to light a lamp [9].

\section{F. Supermarket Sainsbury's, Gloucester, UK}

A supermarket chain called Sainsbury's in the UK opened Gloucoster in your store with a system that generates electricity every time a car in the parking maneuver. The system works by transforming the kinetic energy of the car into electricity from piezoelectric plates is that every time a car passes across the parking lot, he goes over boards placed strategically on the floor, which undergo deformation due to the weight of the car, generate electricity where the system can generate up to $30 \mathrm{~kW}$ per hour [10].

\section{Principles of Generation}

The vibration and mechanical pressure for generating energy used to the principle of piezoelectricity are illustrated in Figure 5, the sequence begins with the conversion of the mechanical energy source, tennis. The pressure imposed by the person who uses the shoes with piezoelectric elements convert this into electrical energy. After this production is given in direct current and require conversion to be used where static converter rectifies $\mathrm{AC}$ voltage continuously.

After converting this energy is stored in the form of the electric field in capacitors for later use load. To further exploit the multi-cell system was used to generate, in view of the effort of foot contact with the ground occurs at different times for each part of the foot, with the first heel contact, and finally the fingers [11].

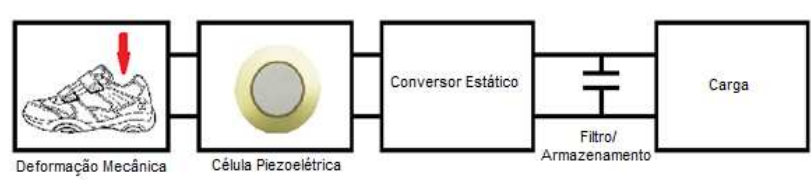

Fig. 5: Diagram Generation Based on Mechanical Energy with the Use of Piezoelectric cell.

\section{Experimental Arrangement}

The project consists of the construction of a footbed from the piezoelectric effect to obtain the generation of electricity. Where this footbed attached to a tennis or shoe uses for power generation in order to charge portable devices where the movement of the person equipment generates uses deformation with its own weight and thereby generate energy to be stored or used instantly.

The construction of the prototype in real dimensions which can evaluate the performance to be improved and further developed on a large scale. This prototype when installed in tennis can be very useful for people who have the habit of practice runs and / or walks, because the energy generated can be used instantly to charge cell phone batteries and flashlights for example.

With this construction has as objective the implementation of piezoelectric cells is to generate energy in different sources and using only the vibration caused by the weight of people, so do not harm nature, takes advantage of a source of energy that is wasted, and ignore. No matter how small the generation, it is important because it comes from something that is not used and is in constant development.

The assembly of the prototype consists of a footbed of a shoe with piezoelectric transducers inserted so that this deformation to walk these operate and generate energy. The size was determined based on a donated shoes size 9.5 (U.S.) with dimensions of $28 \times 11 \mathrm{~cm}$, where this size is enough to condition the transducers and cause deformation required.

The transducers are of type PTZ ceramic with circular shape, for a better utilization of the deformation generated by the movement of walking they were stacked and placed between printed circuit board (PCB) board to improve the mechanical rigidity of the system and realize 
energy transmission generate, the arrangement pattern can see in figure 6.

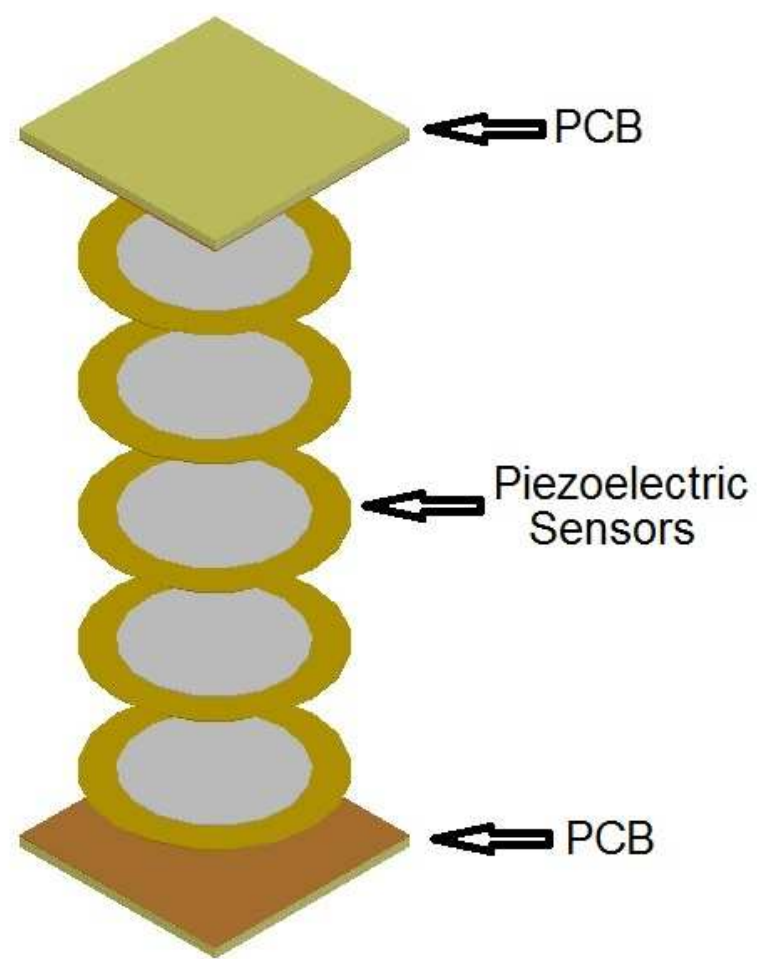

Fig.6: Mounting of Piezoelectric Sensors.

With analyzes of the walking movement and the force on each area of the foot sole, it found that the heel would cause the greater deformation and the toes thus greater amount of piezoelectric sensors concentrated these areas. The transducers were place on the design of the foot and distribute them through the heel and toe, this arrangement can see in Figure 7.

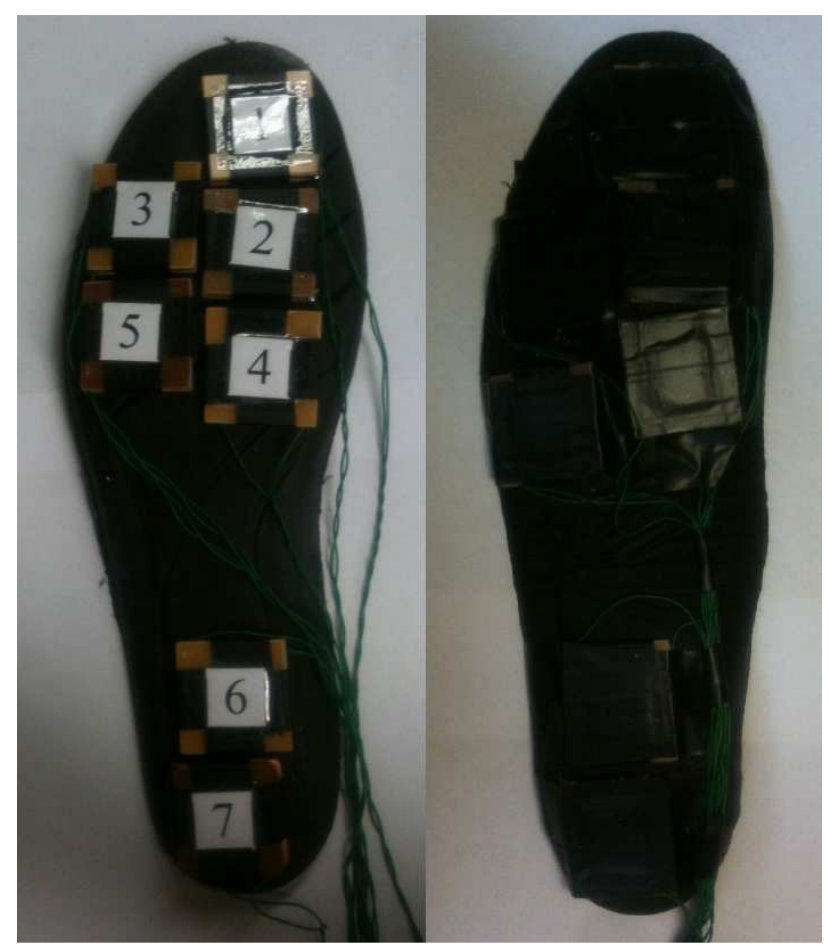

Fig.7: Installation of Piezoelectric Transducers in Footbed.
The attachment of cells on the footbed made with ribbons for the prototype and the space generated by the same bottom was intend to pass the wires connecting the transducers and the rectifying circuit. For a better use of the energy generated by the piezoelectric links with different configurations targeting a high voltage and current generated by the system made, this arrangement can see in Figure 8.

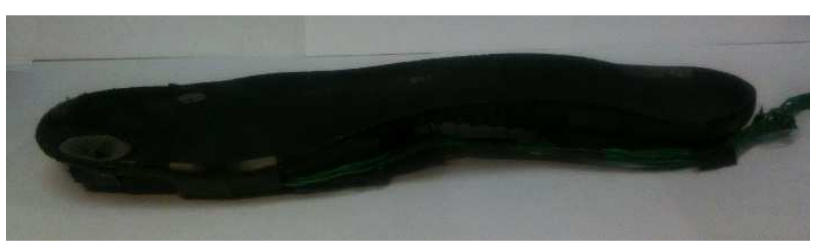

Fig.8: Mounting of Piezoelectric Sensors in Footbed.

The mount for the tests is show in Figure 9.

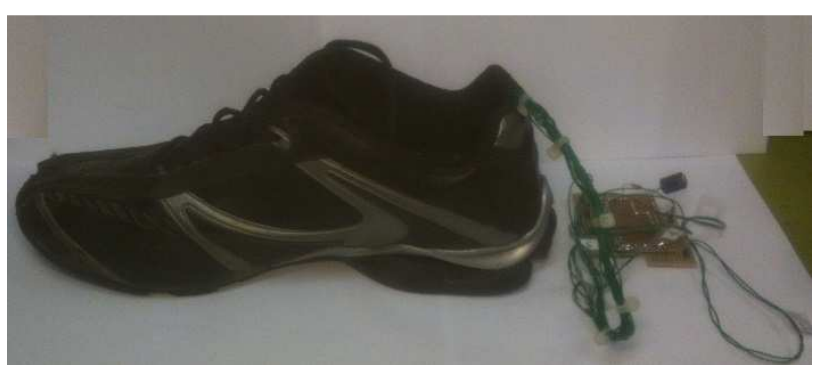

Fig.9: Mounting for Testing.

As described in the system consists of piezoelectric energy capture that after the generation of energy by deformation needs treatment, where this treatment was with a full wave rectification. Which is performer individually for each cell system having aims that each activated at a time during the walking movement, and the storage and discharge of a capacitor with a resistor in parallel with the capacitor, which can carry out the estimation of power generated, the circuit can see in Figure 10.

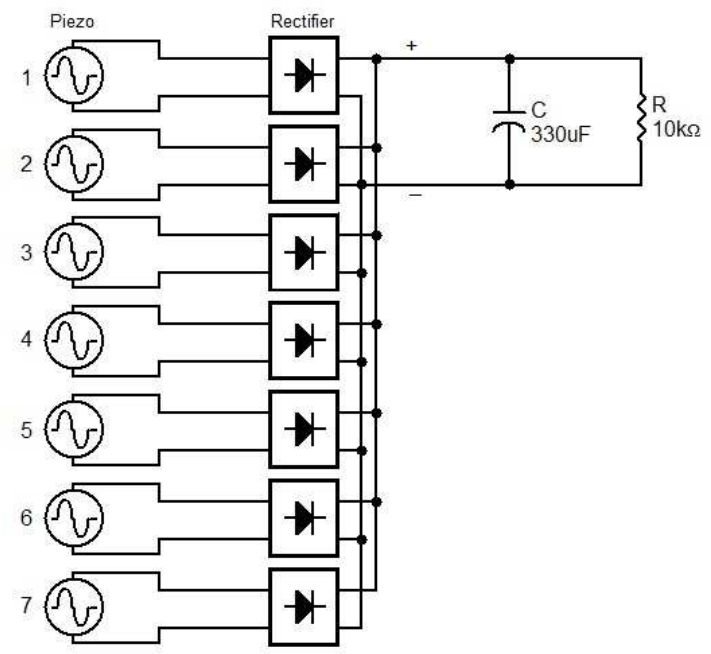

Fig. 10: Circuit for Piezoelectric Energy Funding.

\section{Results}


Tests with the prototype were conducted to determine the power generated by the system, trying to get data for improvements in futures tests. For the tests the footbed is inserted in tennis is after using the weight of a staff walked up to the same time last which was given as a normal walk.

With the measuring equipment connected to the sensor obtained the values of voltage initially generated only by cells using the rectification circuit load and $10 \mathrm{~K} \Omega$ can obtain the values for each time the sensors were pressed. The values vary according to the weight of the user, which is a determining factor for the quantity of power generated, where the weight of an individual obtain by multiplying weight $(\mathrm{kg})$ by gravity.

The larger the weight of an individual, the greater the force that it had generated on the ground, to force on the insole increases, so the deformation of the piezoelectric sensor, and therefore raises the level of system voltage.

In this connection scheme has obtained an rms voltage of $0,35 \mathrm{~V}$ and a peak voltage of $6 \mathrm{~V}$, thus obtaining an rms power of $12,25 \mathrm{uW}$ and a peak power of $3,6 \mathrm{~mW}$. By pulsing the voltage and characteristic for the pure DC voltage was necessary connecting a capacitor in parallel with the output of the rectifier, because thereby the capacitor filters out the noise signal and stores energy, making the voltage constant signal and thus DC voltage. This voltage is stored in the capacitor, and tests without load, the stored voltage was approximately $3,5 \mathrm{~V}$ with an energy of 2,021 mJ.

When connecting a load on the system can determine the system voltage with load current, and power generated. To perform this test with a resistor value of $10 \mathrm{~K} \Omega$ is connect to the output of the system. As the generation has a small value, if it were placed a load with low power because the case fell within the load with a high power system voltage would drop to zero.

With the load connected, obtain the average voltage of $0,2 \mathrm{~V}$ at the load, which can calculate the current generated, which was around 20uA. The power generated by the system in just a few past is $4 \mathrm{uW}$.

\section{Conclusions}

With the study and analysis of material properties, one can find phenomena using energy that is wasted due to the lack of it, the piezoelectric effect is the evidence that one type of mechanical energy that is wasted daily through deformations, however small they may be, can be harnessed to clean energy generation, which justifies its application.

The system by functioning as a whole had the initial ideas, even with small deviations due to the low power output were not significant for the final result given that the principle of generation from piezoelectric transducers was confirmed and only requires improvement.

Performing this work can be stated that the ultimate goal was achieved, and the response by the system was satisfactory for energy generated and initially was and still is wasted when you have any movement that generates a mechanical deformation.

Given the above, it is concluded that the use of one type of energy wasted linked to materials with high energy gain may be a branch for generating clean energy to the electrical system in order to reduce the consumption of polluting source, and with some adjustments to improve the functioning, such as raising the number of transducers, piezoelectric use of larger and more generation capacity and stacking for better use of mechanical energy can bring a level of energy generation high.

\section{References}

[1] CALlister JÚNIOR, William D. Ciência e engenharia de materiais: uma introdução. 5.ed Rio de Janeiro: LTC, 2002. 589 p.

[2] REZENDE, Sergio M. Materiais e dispositivos eletrônicos. 2. ed São Paulo: Livraria da Física, 2004. 547 p.

[3] VAN VLACK, Lawrence H. Princípios de ciência e tecnologia dos materiais. 4. ed., atual., ampl Rio de Janeiro: Elsevier; Campus, 2003. 567p.

[4] PEREIRA, Antônio Henrique Alves. Atcp Engenharia Física (Org.). Cerâmicas piezoelétricas: funcionamento e propriedades. São Carlos, 2010. 7 p.

[5] SPITZCOVSKY, Débora. Super Interessante. Energia na pista de dança. Disponível em: <http://super.abril.com.br/blogs/planeta/energia-na-pistade-danca/>. Acesso em: 09 jul. 2013.

[6] TECNOPRESS. Piezoeletricidade, gerar energia andando. Disponível em: <http://tecnopress.wordpress.com/2008/12/22/piezoeletrici dade-gerar-energia-andando/>. Acesso em: 09 jul. 2013.

[7] ELOI, Gustavo. Revista Sustenta. Gerando energia elétrica através do fluxo no trânsito. Disponível em: $<$ http://eletrocuriosidades.blogspot.com/2011/09/gerandoenergia-eletrica-atraves-do.html>. Acesso em: 09 jul. 2013.

[8] PEREIRA, Carolina Daemon Oliveira. Energia piezoelétrica. Disponível em: <http://caroldaemon.blogspot.com.br/2010/11/energiapiezoeletrica.html>. Acesso em: 09 jul. 2013.

[9] JULIÃO, André. Isto É. Energia limpa sob nossos pés. Disponível

em: <http://www.istoe.com.br/reportagens/73214_ENERGIA+ LIMPA+SOB+NOSSOS+PES >. Acesso em: 09 jul. 2013.

[10] JACOMEL, Gabriella Eduarda. Isto É. Supermercado britânico gera energia do movimento nos estacionamentos. Disponível em: <http://conhecimentosgeraisalgosobre.blogspot.com.br/2011/05/supermercadobritanico-gera-energia-do.html>. Acesso em: 09 jul. 2013.

[11] MINAZARA, Ericka; VASIC, Dejan; COSTA, François. Piezoelectric Generator Harvesting Bike Vibrations Energy to Supply Portable Devices. In ICREPQ, 2008, Cordoba. ICREPQ 2008, 6p. 